\title{
PERAN ORANG TUA DALAM PEMBELAJARAN DARING PADA MASA PANDEMI COVID-19 SISWA KELAS III SDIT AT-TAQWA GARUDA KABUPATEN TANGERANG
}

\author{
${ }^{1}$ Zahra khoerunisa, ${ }^{2}$ Septy Nurfadhillah, ${ }^{3}$ Sa'odah \\ ${ }^{123}$ Universitas Muhammadiyah Tangerang \\ zahrakhoerunisa@gmail.com
}

\begin{abstract}
Abstrak
Penelitian ini bertujuan untuk mengetahui peran yang dilakukan oleh orang tua dalam pembelajaran daring pada masa pandemi Covid-19 siswa kelas III SDIT At-Taqwa Garuda Kabupaten Tangerang. Penelitian ini merupakan penelitian kualitatif dengan menggunakan metode penelitian kualitatif deskriptif. Subjek dalam penelitian ini adalah guru kelas III, siswa dan orang tua siswa. Teknik pengumpulan data dilakukan adalah observasi pembelajaran daring yang dijalani siswa, wawancara dengan guru kelas III dan orang tua siswa serta studi dokumen. Hasil penelitian menunjukkan bahwa orang tua berperan sebagai; 1) guru di rumah dengan membimbing siswa dalam belajar, 2) fasilitator dengan memenuhi kebutuhan yang diperlukan untuk proses pembelajaran daring, 3) motivator dengan memberikan dorongan serta semangat belajar kepada siswa dan 4) pengaruh yang mengawasi dan mengingatkan siswa untuk terus disiplin dalam belajar dan bertanggung jawab terhadap tugasnya. Dengan begitu peran orang tua dalam pembelajaran daring ini sangat penting agar proses pembelajaran daring yang dilakukan berjalan dengan tertib dan kondusif.
\end{abstract}

Kata Kunci: peran orang tua, pembelajaran daring

\begin{abstract}
This study aims to determine the role played by parents in online learning during the Covid-19 pandemic for third grade students of SDIT At-Taqwa Garuda Tangerang Regency. This research is a qualitative research using descriptive qualitative research methods. The subjects in this study were third grade teachers, students and parents. The data collection techniques used were online learning observations by students, interviews with third grade teachers and student's parents, and document studies. The results showed that parents played a role as; 1) teachers at home by guiding students in learning, 2) facilitators by meeting the needs needed for the online learning process, 3) motivators by providing encouragement and enthusiasm for learning to students and 4) influences that supervise and remind students to continue to be disciplined in learning and responsible for their duties. Thus, the role of parents in online learning is very important so that the online learning process is carried out in an orderly and conducive manner.
\end{abstract}

Keywords : the role of parents, online learning. 


\section{PENDAHULUAN}

Pendidikan merupakan suatu proses belajar dan pembelajaran yang dilakukan secara menyeluruh dan terencana, dilakukan tidak hanya untuk kecerdasan otak namun juga untuk kecerdasan emosional dan sikap, dengan tujuan menghasilkan manusia-manusia yang mampu untuk hidup dengan benar dan dapat bermanfaat bagi dirinya, masyarakat, bangsa dan negara. Selain itu, pendidikan juga sangat membantu manusia untuk mendewasakan diri agar mampu untuk menyelesaikan persoalan dan permasalahan di hidupnya. Dengan begitu, pendidikan ini tentulah merupakan sesuatu yang tidak bisa lepas dari kehidupan manusia.

Menurut Undang-Undang Dasar 1945 Pasal 31 Ayat 1 menyebutkan bahwa "Setiap warga negara berhak mendapat pendidikan”. Oleh karena itu setiap warga negara yang usianya sudah cukup, maka wajib untuk masuk dan mengikuti pendidikan formal yang sudah ditetapkan. Dan pemerintah wajib untuk membiayai pendidikan tersebut.

Agar seluruh warga negara dapat memenuhi hak mendapat pendidikan, maka diperlukan keterlibatan antara guru, orang tua bahkan siswa itu sendiri. Semua pihak haruslah menjalankan tugas, tanggung jawab dan kewajibannya dengan baik. Agar tujuan pembelajaran yang sudah ditentukan tetap dapat tercapai.

Di masa pandemi Covid-19 seperti ini, sistem pembelajaran yang dilakukan pun berubah, dari pembelajaran konvensional di kelas menjadi pembelajaran daring (dalam jaringan) yang dilakukan dari rumah. Perubahan mendadak seperti ini sering kali membuat pihak-pihak dalam pembelajaran kurang siap atau terkendala dalam melakukan peran dan tugasnya.

Ketika pembelajaran daring berlangsung, idealnya adalah orang tua mampu menjadi mendamping dan pembimbing bagi anaknya dalam belajar. Sehingga pesan yang disampaikan guru tetap dapat diterima dengan baik oleh siswa dan tujuan yang ditentukan pun tetap dapat tercapai walaupun melalui cara pembelajaran yang berbeda yaitu komunikasi tidak langsung menggunakan gawai/gadget.

Walaupun pada kenyataannya orang tua tidak hanya berperan sebagai pendamping dan pembimbing, namun juga ada yang berperan sebagai fasilitator dengan menyediakan atau memberikan les untuk anaknya, sebagai pengawas yang mengawasi anaknya dalam belajar, bahkan ada pula yang berperan sebagai pengganti anaknya dalam belajar ataupun mengerjakan tugas. 
Dari kondisi inilah, peneliti tertarik untuk melakukan penelitian dengan judul "Peran Orang Tua dalam Pembelajaran Daring pada Masa Pandemi Covid-19 Siswa Kelas III SDIT At-Taqwa Garuda Kabupaten Tangerang”.

\section{Peran Orang Tua}

Ketika seseorang sudah memutuskan perannya untuk menjadi orang tua, maka ia harus mempersiapkan segala hal, bukan hanya kesiapan materi saja namun juga kesiapan mental. Menurut Warsah (2020), “orang tua berperan sebagai pendidik adalah dengan mengasuh, membimbing, memberi teladan, dan membelajarkan anak" (Maimunawati dan Alif, 2020, h. 28). Peran ini sangat penting bagi anak, karena pendidikan yang diberikan orang tua tersebut akan membentuk pribadi anak saat dewasa nanti dan itu berpengaruh bagi kelangsungan hidupnya di masa depan.

Selain itu, menurut Nopitasari dan Indriana (2020), peran orang tua terutama pada masa pandemi Covid-19 adalah menjaga kesehatan anggota keluarganya dan dalam mendidik anakanaknya (h.46). Jika pada tahun-tahun sebelumnya orang tua biasanya cukup memberikan makanan bergizi untuk tumbuh kembang anaknya. Namun pada masa pandemi seperti ini perlu ditingkatkan lagi usaha orang tua dalam menjaga kesehatan anak-anaknya dan seluruh anggota keluarganya.

Dari pendapat tersebut dapat dipahami bahwa peran orang tua adalah usaha memberikan dan memfasilitasi semua kebutuhan anak baik jasmani ataupun rohaninya, mendidik dan memberikan pendidikan yang sesuai untuk perkembangan minat dan bakatnya, memberikan teladan serta mengawasi anak dalam prosesnya menuju dewasa.

\section{Pembelajaran Daring}

Pembelajaran daring (dalam jaringan) biasa juga disebut dengan pembelajaran jarak jauh (PJJ). Tidak hanya itu, banyak penyebutan lain yang bermakna sama, seperti e-leaning, online learning, mobile learning, internet learning, web-based learning, tele-learning dan lain sebagainya. Walaupun penyebutannya berbeda-beda, tetapi sistem pembelajaran yang dilakukan adalah sama yaitu pembelajaran yang dilakukan secara tidak langsung dengan memanfaatkan dukungan teknologi informasi komunikasi seperti internet, jaringan, komputer, gawai ataupun yang lainnya. 
Secara terminologi, pembelajaran daring adalah sebuah proses pembelajaran yang dilakukan melalui network (jaringan komputer), biasanya lewat internet atau intranet. Menurut Munir (2012), "E-learning berarti proses transformasi pembelajaran dari yang berpusat pada pengajar kepada berpusat pada pembelajar" (h. 170). Jadi pembelajaran yang dilakukan tidak hanya tergantung kepada guru sebagai pengajar, karena pengetahuan dan informasi menjadi lebih luas dan lengkap sehingga siswa juga dapat belajar atau mengakses materi dimana pun dan dikapan pun.

Menurut Belawati (2019), "Pembelajaran online adalah proses belajar mengajar yang dilakukan dalam dan dengan bantuan jaringan internet" (h. 8). Jadi, proses pembelajarannya tetap sama dengan pembelajaran yang biasa dilakukan di kelas seperti guru memberikan materi, lalu siswa melakukan umpan balik dengan menjawab pertanyaan-pertanyaan secara langsung maupun berupa soal, hanya saja kegiatan tersebut dilakukan melalui jaringan internet.

Dari beberapa pendapat ahli tersebut, dapat dipahami bahwa pembelajaran daring adalah interaksi belajar yang dilakukan oleh guru, siswa dan sumber belajar dengan memanfaatkan jaringan internet serta teknologi informasi dan komunikasi (TIK).

Setiap pembelajaran mempunyai karakteristik atau cirinya tersendiri, begitu pula dengan pembelajaran daring. Menurut Munir (2012, h. 170-171) karakteristik e-learning antara lain:

1) Memanfaatkan jasa teknologi elektronik sehingga dapat memperoleh informasi dan melakukan komunikasi dengan mudah dan cepat, baik antara pengajar dengan pembelajar, atau pembelajar dengan pembelajar.

2) Memanfaatkan media komputer, seperti jaringan komputer (computer networks atau digital media).

3) Menggunakan materi pembelajaran untuk dipelajari secara mandiri (self learning materials).

4) Materi pembelajaran dapat disimpan di komputer, sehingga dapat diakses oleh pengajar dan pembelajar, atau siapa pun tidak terbatas waktu dan tempat kapan saja dan di mana saja sesuai dengan keperluannya.

5) Memanfaatkan komputer untuk proses pembelajaran dan juga untuk mengetahui hasil kemajuan belajar, atau administrasi pendidikan, serta untuk memperoleh informasi yang banyak dari berbagai sumber informasi. 
Ciri-ciri itulah yang membedakan antara pembelajaran konvensional dengan pembelajaran daring. Jadi ketika suatu pembelajaran memuat ciri-ciri yang telah disebutkan dan dijabarkan tersebut, maka dapat dikatakan bahwa pembelajaran tersebut merupakan pembelajaran daring.

\section{Pandemi Covid-19}

Virus Corona (CoV) adalah keluarga besar virus yang dapat menginfeksi burung dan mamalia, termasuk manusia. Menurut World Health Organization (WHO) virus ini menyebabkan penyakit mulai dari flu ringan hingga infeksi pernapasan yang lebih parah seperti MERS-CoV dan SARS-CoV.

Virus Corona muncul di kota Wuhan, Cina tahun 2019 dan sejak itu menyebar ke berbagai negara. Berdasarkan keterangan yang dikeluarkan oleh pemerintah Cina, asal mula wabah ini adalah pasar hewan laut di Wuhan. Namun Presiden Amerika Serikat (AS) Donald Trump mengklaim memiliki bukti, virus Corona ini dikembangkan di sebuah laboratorium di Wuhan, Cina yang menjadi pusat wabah. Namun para ilmuwan mengatakan tak ada bukti yang membenarkan klaim Donald Trump tersebut.

Wabah Coronavirus Disease 2019 (Covid-19) secara resmi menginfeksi masyarakat Indonesia pada Maret 2020. Namun pemerintah Indonesia tidak langsung memberlakukan lockdown (karantina), tetapi sejumlah wilayah di Indonesia telah melakukan local lockdown atau karantina wilayah.

Saat ini Indonesia masih bergelut dengan virus corona, sama dengan negara lain di dunia. Jumlah kasusnya terus bertambah dengan beberapa melaporkan kesembuhan, namun tidak sedikit pula yang meninggal. Usaha penanganan dan pencegahan terus dilakukan demi melawan Covid-19 dengan gejala mirip flu.

Kasus Covid-19 di Indonesia masih didominasi di wilayah perkotaan. Hal ini disampaikan pakar epidemolog, Dewi Nur Aisyah, menurut data yang dia kumpulkan kota di Indonesia yang berjumlah 98 masih selalu "juara" dalam hal kasus Covid-19. Dewi mengatakan jika dilihat jumlah kasus Covid-19 di Indonesia, kota menyumbangkan angka kasus sebanyak 64,3\%, dan juga angka kematian lebih banyak (Sari dan Habibi, 2020, h.35).

Sedangkan kondisi di desa semakin terbebani saat pandemi Covid-19 terjadi, terlebih dengan pulangnya urban yang telah sampai di kampung halaman karena membawa kecemasan 
terjadinya transmisi lokal virus corona. Kota besar banyak dikunci dengan pembatasan sosial berskala besar (PSBB), berbeda dengan desa yang digenjot perekonomiannya.

Warga desa bukanlah penduduk yang kebal virus, namun mereka harus tetap memproduksi hasil pertanian untuk menghidupi diri dan menyangga kehidupan kota. Kota besar istirahat sementara waktu hingga pandemi berlalu, sementara desa dipacu untuk tetap memutarkan sendi-sendi ekonomi supaya bahan pangan penyangga kehidupan tidak terhenti.

Dampak pandemi Covid-19 ini tidak hanya mengenai sistem perekonomian saja, namun juga berdampak kepada sistem pendidikan yang ada di Indonesia. Berdasarkan Surat Edaran Mendikbud Nomor 4 Tahun 2020 tentang Pelaksanaan Kebijakan Pendidikan dalam Masa Darurat Penyebaran Corona Virus Disease (Covid-19) yang dikeluarkan oleh Menteri Pendidikan dan Kebudayaan Nadiem Makarim pada Selasa 24 Maret 2020, yang berisikan bahwa proses belajar mengajar atau pembelajaran dilakukan dari rumah. Hal ini dilakukan untuk melindungi setiap warga pendidikan dari dampak buruk Covid-19, mencegah penularan dan penyebaran Covid-19 di satuan pendidikan dan memastikan pemenuhan hak peserta didik untuk mendapatkan pendidikan selama masa darurat Covid-19 ini tetap terlaksana. Oleh karena itu, orang tua diharapkan dapat berperan aktif dalam pembelajaran di rumah agar tujuan pendidikan yang telah ditetapkan dapat tercapai walaupun dengan sistem pembelajaran yang berbeda.

\section{Perang Orang Tua dalam Pembelajaran Daring}

Sejak pandemi Covid-19 melanda Indonesia, pemerintah menetapkan bahwa pembelajaran dilakukan dari rumah. Oleh karena itu, orang tua mempunyai peran tambahan seperti membimbing dan menemani anaknya dalam pembelajaran daring.

Menurut Winingsih (2020) dalam Haerudin, Cahyani, Sitihanifah, Setiani, Nurhayati, Oktaviana, Sitorus (2020, h. 4) ada empat peran yang dihadapi oleh orang tua selama pembelajaran jarak jauh (PJJ) atau pembelajaran daring, yaitu:

a. Sebagai guru di rumah, yang membimbing anaknya dalam belajar di rumah.

b. Sebagai fasilitator, yang menyediakan sarana dan prasarana bagi anaknya dalam melakukan pembelajaran jarak jauh tersebut.

c. Sebagai motivator, yang memberikan semangat serta dukungan kepada anaknya dalam melaksanakan pembelajaran, sehingga anak semakin semangat dalam meraih prestasi. 
d. Sebagai pengaruh, yang mempengaruhi hasil belajar anaknya selama pembelajaran jarak jauh.

Setelah orang tua mampu memahami perannya dalam pembelajaran, Siregar (2013) dalam Lilawati (2020, h.552) menambahkan bahwa ada empat cara untuk meningkatkan peran orang tua dalam pendidikan anak-anak, yaitu: (a) Atur jadwal kegiatan dan waktu anak, (b) Pantau perkembangan kemampuan akademik, (c) Pantau perkembangan kepribadian, dan (d) Pantau efektivitas waktu sekolah. Dari keempat peran orang tua tersebut diharapkan kegiatan pembelajaran selama daring dapat terlaksana secara efektif dan baik.

\section{METODE PENELITIAN}

Penelitian ini dilakukan di SDIT At-Taqwa Garuda Kabupaten Tangerang. Penelitian ini menggunakan pendekatan penelitian kualitatif, sebagaimana menurut menurut Satori dan Komariah (2017) "penelitian kualitatif adalah penelitian yang menekankan pada quality atau hal yang terpenting dari sifat suatu barang atau jasa" (h. 22).

Jenis metode penelitian yang digunakan yaitu penelitian kualitatif deskriptif. Menurut Mawardi (2019) "penelitian deskriptif adalah penelitian yang berusaha mendeskripsikan suatu gejala, peristiwa, kejadian yang terjadi saat sekarang" (h. 41). Melalui metode ini, peneliti berusaha mendeskripsikan secara jelas dan terperinci.

Jenis data dalam penelitian ini adalah data primer, yaitu data yang diperoleh secara langsung dan data sekunder, yaitu data yang sudah tersedia di tempat penelitian. Sumber dalam penelitian ini adalah guru kelas III, siswa dan orang tua siswa. Teknik pengumpulan data melalui observasi, wawancara dan studi dokumentasi.

Analisis data dalam penelitian kualitatif dilakukan sejak sebelum memasuki lapangan, selama di lapangan dan setelah selesai di lapangan. Menurut Sugiyono (2016) "Analisis data dalam penelitian kualitatif, dilakukan pada saat pengumpulan data berlangsung, dan setelah selesai pengumpulan data dalam periode tertentu" (h. 246). Jadi selama proses penelitian masih berlangsung, analisis itu terus dilakukan sampai penelitian selesai dan hasil analisisnya didapatkan.

Teknik analisis data dalam penelitian ini diolah berdasarkan analisis kualitatif. Model yang digunakan dalam analisis kualitatif ini adalah Model Miles dan Huberman (1984) yaitu reduksi data, penyajian data dan penarikan kesimpulan. 


\section{HASIL DAN PEMBAHASAN}

Penelitian dengan judul "Peran Orang Tua dalam Pembelajaran Daring pada Masa Pandemi Covid-19 Siswa Kelas III SDIT At-Taqwa Garuda Kabupaten Tangerang" merupakan sebuah penelitian yang bertujuan untuk mengetahui peran orang tua dalam pembelajaran daring pada masa pandemi Covid-19.

Berdasarkan hasil observasi, wawancara dan studi dokumentasi, dapat diketahui bahwa Orang tua berperan sebagai guru di rumah yang membimbing dan mendampingi siswa dalam belajar. Bimbingan dan pendampingan yang dilakukan berupa membantu siswa ketika mengalami kesulitan dalam belajar atau mengerjakan tugas, mengecek hasil belajar siswa dan membantu untuk mengoreksi jika jawaban yang dikerjakan siswa masih belum tepat.

Orang tua juga berperan sebagai fasilitator, yang memfasilitasi siswa dalam mengikuti pembelajaran daring ini. Fasilitas belajar yang diberikan berupa penyediaan smartphone, buku belajar, alat tulis dan bahkan mengikuti belajar tambahan atau les. Penyediaan smartphone ini tidak selalu menjadi milik pribadi siswa, ada juga yang digunakan bersama dengan orang tua terutama ibunya. Walaupun ada siswa yang memiliki smartphone sendiri, hal tersebut tetap dalam pengawasan orang tua.

Selanjutnya orang tua juga berperan sebagai motivator. Walaupun secara keseluruhan siswa masih semangat dalam mengikuti pembelajaran daring, namun ada saja saatnya siswa merasa tidak semangat dan malas dalam belajar. Faktornya bisa dikarenakan perubahan mood atau suasana hari, sulit dalam memahami materi, ingin bermain, atau bahkan bosan dan jenuh selalu belajar dari rumah. Namun demikian, orang tua selalu memberikan motivasi dan semangat kepada siswa, baik dengan menggunakan kata-kata, memberikan penjelasan tentang materi yang sulit dimengerti oleh siswa sampai paham, memberi pengertian tentang kewajiban dan hak sehingga siswa dapat memahami waktu belajar dan waktu bermainnya ataupun memberikan camilan seperti makanan dan minuman untuk mengembalikan semangat belajar siswa.

Orang tua pun berperan sebagai pengaruh bagi proses dan hasil belajar siswa. Karena pembelajaran daring ini dilakukan dari rumah, maka orang tua lah yang akan selalu mengingatkan dan mempengaruhi siswa untuk terus disipilin dalam belajar. Siswa diberikan pemahaman tentang kewajiban dan haknya sebagai pembelajar dan anak. Sehingga siswa akan 
paham dan mengerti tanggung jawabnya untuk belajar terlebih dahulu barulah ia bisa melakukan kegiatan lain seperti bermain atau yang lainnya.

Berdasarkan hasil temuan tersebut, dapat diketahui bahwa beberapa peran orang tua dalam pembelajaran, yaitu sebagai guru di rumah yang membimbing siswa dalam belajar, sebagai fasilitator yang menyediakan kebutuhan belajar siswa, sebagai motivator yang memberikan semangat kepada siswa dan sebagai pengaruh yang mempengaruhi siswa dalam belajar.

\section{SIMPULAN DAN SARAN}

Setelah peneliti menguraikan data-data yang telah diperoleh selama penelitian dengan judul "Peran Orang Tua dalam Pembelajaran Daring pada Masa Pandemi Covid-19 Siswa Kelas III SDIT At-Taqwa Garuda Kabupaten Tangerang”. Maka peneliti dapat menarik kesimpulan bahwa ada beberapa peran orang tua dalam pembelajaran daring, yaitu sebagai guru di rumah yang membimbing dan mendampingi siswa dalam belajar dan membantu mengatasi kesulitan pembelajaran, sebagai fasilitator yang memenuhi kebutuhan dan hal-hal yang diperlukan untuk pembelajaran daring seperti smartphone, buku-buku, alat tulis dan lainnya, sebagai motivator yang memberikan motivasi, dorongan serta semangat kepada siswa agar ia bisa terus semangat dalam mengikuti pembelajaran selama masa pandemi, dan juga sebagai pengaruh yang selalu mengingatkan dan mempengaruhi siswa untuk terus disiplin dalam belajar serta memenuhi tanggung jawabnya yaitu mengerjakan tugas.

Berdasarkan hasil penelitian, pembahasan serta kesimpulan yang telah diuraikan, ada beberapa saran yang dapat peneliti sampaikan, yaitu: Orang tua diharapkan dapat membimbing dan mendampingi siswa dalam belajar, menciptakan situasi belajar yang kondusif, memberikan fasilitas yang dibutuhkan siswa mendukung kelancaran pembelajaran daring dan terus memberikan perhatian serta motivasi agar siswa terus semangat dalam mengikuti pembelajaran daring. Adapun saran untuk guru yaitu : Guru diharapkan dapat membuat suasana belajar yang menyenangkan dan mudah dipahami agar siswa terus semangat dalam belajar dan guru diharapkan dapat berkoordinasi dan mengkomunikasikan hal-hal penting dalam pembelajaran dengan orang tua siswa. 


\section{DAFTAR PUSTAKA}

Belawati, T. (2020). Pembelajaran Online. Tangerang : Universitas Terbuka.

Haerudin, dkk. (2020). Peran Orang Tua dalam Membimbing Anak Selama Pembelajaran Daring di Rumah. Prosiding Seminar Nasional Pengabdian Masyarakat LPPM L 806 4. Diakses 28 April 2021 dari Universitas Muhammadiyah Jakarta.

Lilawati, A. (2020). Peran Orang Tua dalam Mendukung Kegiatan Pembelajaran di Rumah pada Masa Pandemi. Jurnal Obsesi : Jurnal Pendidikan Anak Usia Dini, 5(1), 552. Diakses 28 April 2021 dari Universitas Pahlawan.

Maimunawati, Siti dan Muhammad Alif. (2020). Peran Guru, Orang Tua, Metode dan Media Pembelajaran : Strategi KBM di Masa Pandemi Covid-19. Serang : 3M Media Karya.

Mawardi. (2019). Dasar-Dasar Metodologi Penelitian Pendidikan. Yogyakarta : Samudra Biru.

Munir. (2012). Pembelajaran Jarak Jauh Berbasis Teknologi Informasi dan Komunikasi. Bandung : Alfabeta.

Nopitasari, Lidya Kandau dan Dina Indriana. (2020). Peran Guru dan Orang Tua dalam Mendidik Anak Selama Masa Pandemi Covid-19. Serang : Media Madani.

Sari, Sahira Kartika dan Habibi. (2020). Implementasi Pembelajaran Daring di Masa Pandemi Covid-19 di Tingkat SD/MI. Serang : Media Madani.

Satori, D dan Aan Komariah. (2017). Metodologi Penelitian Kualitatif. Bandung : Alfabeta Sugiyono. (2016). Metode Penelitian Kuantitatif, Kualitatif dan R\&D. Bandung : Alfabeta. 